DOI: $10.1515 /$ pof-2015-0022

VOLUME 7, ISSUE 3, 2015

ISSN: $2036-5438$

\title{
The European Stability Mechanism: Human Rights Concerns Without Responsibilities?
}

by

\author{
Arianna Vettorel*
}




\begin{abstract}
The current financial problems of some Euro-area Member States have been tackled by ad hoc financial institutions, formed outside of the EU as international institutions and aimed at granting financial assistance on the basis of strict conditionality measures, which seriously affect human rights (particularly social and economic rights).

The paper focuses on the impact of the actions of the European Stability Mechanism and analyses whether this institution (or the European institutions and the Member States involved in it) should bear the responsibility for such violations.
\end{abstract}

\title{
Key-words
}

European Stability Mechanism, Memoranda of Understanding, conditionality measures, human rights, responsibility 


\section{Introduction}

In recent times, the Eurozone Member States (MS) have devised complex international financial mechanisms, tightly linked to themselves and European Union (EU) institutions but formally set outside the EU. These mechanisms were necessary because of the EU's perceived inability to help MS, and the Eurozone MS in particular, to get out of the crisis. Indeed, in the same way as the no bail out clause ${ }^{\mathrm{I}}$ prevents the Union from assuming the commitments of central Governments, the Treaty on the Functioning of the EU (TFEU), in turn prevents 'national central banks' from financing public debt. ${ }^{\mathrm{II}} \mathrm{It}$ is in this context that extra-EU mechanisms have been created to support Eurozone MS by avoiding the economic crisis's effects in those MS experiencing financial difficulties and combating these effects in the Euro-area as a whole.

However, as legal scholars have already explained, these financial institutions undermine the stability and legitimacy of the EU project (Dawson and de Witte 2013; see also Joerges 2014: 1109-1013 on the implications of the new modes of European economic governance for the EU's state). Moreover, such mechanisms jeopardize the protection of human rights (particularly social and economic rights) for citizens and inhabitants of MS in receipt of aid, as a consequence of conditionality measures attached to financial assistance.

After briefly analyzing how the financial crisis has been managed, this article will focus on human rights concerns that stem from these strict conditionality measures, and on the responsibility for possible human rights violations, with particular regard to the European Stability Mechanism (ESM) framework.

\section{Managing the crisis}

\subsection{Financial devices: the EFSM, the EFSF, the ESM}

In order to address the crisis of sovereign debt, three financial stability mechanisms have been created: the European Financial Stabilization Mechanism (EFSM), the European Financial Stability Facility (EFSF) and the ESM. Such measures, aimed at granting assistance to avoid the risk of State failure as a consequence of market failure, are also known as "Rescue Funds". 
The EFSM was established by EU Regulation No. 407/2010, ${ }^{\text {III }}$ on the basis of Article 122(2) TFEU, to grant Union financial assistance to a MS affected by or seriously threatened with a severe economic or financial disturbance caused by exceptional occurrences beyond its control. According to Article 3(2) of this Regulation, such assistance is granted via a decision adopted by the European Council, which essentially dictates the payment methods and the economic conditions attached to the Union's financial assistance. The EFSM, however, could only provide financial assistance of up to $€ 60$ billion, through a joint process between the EU and the International Monetary Fund (IMF); ${ }^{\mathrm{IV}}$ and the total amount provided for the EFSM was, therefore, quite low in the context of the ongoing economic crisis.

Thus, in order to increase the amount of financial assistance available, new steps were necessary; for this reason the Euro-area MS signed an agreement to establish the EFSF, a public limited liability company (société anonyme) incorporated in and governed by the laws of Luxembourg, with its registered office in Luxembourg-City. ${ }^{\mathrm{V}}$ The EFSF was funded by the Euro-area MS as shareholders, while its decisions were made by the EFSF's governing bodies. This early mechanism granted financial assistance to Ireland, Portugal and Greece but was just a temporary measure. ${ }^{\text {VI }}$ This temporary aspect notwithstanding its significant financial capacity ( $€ 440$ billion), ${ }^{\text {VII }}$ led the Euro-area MS to adopt the ESM as a replacement for the EFSF, and to assume the tasks fulfilled by it. ${ }^{\text {VIII }}$

The ESM is, in contrast, a permanent financial mechanism with a lending capacity of up to $€ 500$ billion ("including the outstanding EFSF stability support"), ${ }^{\text {IX }}$ established through an international agreement signed on 2 February 2012 between Euro-area MS, in accordance with the previous Decision No. 2011/199 of the European Council of December 2010. ${ }^{\mathrm{x}}$ The amendment of Article 136 TFEU was made on the basis of Article 48 TFEU, which governs the simplified revision process. ${ }^{\mathrm{XI}}$ Such an amendment was necessary in order to create the ESM financial mechanism and avoid infringements of the TFEU, in particular the no bail out clause, enshrined in Article 125 TFEU (Napolitano 2012).

The Preamble of the ESM Treaty states that the ESM, in connection with the "Treaty on Stability, Coordination and Governance in the Economic and Monetary Union" (TSCG), commonly known as the "Fiscal Compact", XII fosters fiscal responsibility and solidarity within the economic and monetary union. Its aim is then more specifically mentioned in Article 3 of the ESM Treaty, which specifies that financial support will be 
provided to the benefit of ESM Members experiencing or threatened by severe financing problems, if such support is indispensable to safeguard both the stability of the Eurozone as a whole and that of its MS. The ESM can grant assistance in three ways: it may decide to a) arrange for the purchase of an ESM Member's bonds on the primary market; b) arrange for operations on the secondary market in relation to the bonds of an ESM Member; or c) grant financial assistance through loans to an ESM Member for the specific purpose of recapitalizing that Member's financial institutions.

Such assistance, as has already been provided to Cyprus, Spain and Greece, ${ }^{\mathrm{XIII}}$ is granted on the basis of a decision by the Board of Governors, composed of representatives of Governments. ${ }^{X I V}$ The financial assistance facility agreement is then approved by the Board of Directors, the other ESM body, composed of Governors' representatives. ${ }^{\mathrm{XV}}$ Thus, while adopted by ESM bodies, financial assistance decisions are in fact steered by the ESM's shareholding States. Notwithstanding the fact that ESM bodies formally adopt decisions, it is worth noting the important role played by two EU institutions - namely the European Commission (EC) and the European Central Bank (ECB) - in the granting of financial assistance to a requesting Euro-area MS. Indeed, once the State involved has asked the President of the Board of Governors for financial assistance, the EC, together with the ECB and the IMF, has to evaluate the risk the State's instability would bring to the stability of the Euro-area as a whole. ${ }^{\mathrm{XVI}}$ When such a risk is identified, and after the decision of the Board of Governors on the granting of financial assistance, the EC must negotiate a Memorandum of Understanding (MoU), containing strict conditionality measures attached to the provision of financial assistance. ${ }^{\mathrm{XVII}}$ The EC then signs this document $^{\mathrm{XVIII}}$ and the Board of Directors approves the financial assistance facility agreement detailing the financial aspects of the stability support. ${ }^{\mathrm{XIX}}$

Thus, like Euro-area MS, which are represented in the ESM's bodies discussed above, the $\mathrm{EC}$ and the ECB are also relevant actors in the process of granting assistance.

2.2. The procedure to grant financial assistance and ESM compatibility with the no bail out clause: the role played by the conditionality measures

Since the ESM, like its predecessor the EFSF, ensures financial assistance on the basis of decisions adopted by Euro-area MS representatives, and through a procedure that also 
involves the EC and the ECB, there has been a question whether the ESM's actions in fact constituted a violation of the no bail out clause.

Specifically, the possibility of establishing such a permanent stability mechanism has been challenged before the European Court of Justice (ECJ) in the Pringle case. ${ }^{\mathrm{xx}}$ In the judgment, the ECJ, after having affirmed the validity of Decision No 2011/199 (de Witte and Beukers 2013; De Lhoneux and Vassilopoulos 2014; Van Malleghem 2013), ${ }^{x x I}$ addressed the question of whether Euro-area MS were allowed to enter into the ESM Treaty according to EU law. Such an issue, which concerns the validity of posterior agreements concluded by MS inter se, is not specifically addressed in Article 351 TFEU (Klabbers 2008: 205-211; de Witte 2000: 31-58). However, Member States' ability to enter into such agreements is traditionally admitted when there is no exclusive competency of the EU in that area, and where the agreement complies with EU primary law. This assumption has been confirmed by the ECJ, which, in Pringle, stated that the ESM does not affect the exclusive competency of the EU, ${ }^{\mathrm{XXI}}$ and also affirmed that the ESM complies with EU law. In particular, the ESM Treaty does not infringe the no bail out clause, as the EU institutions involved are not acting by themselves within the ESM framework and the ESM grants financial assistance in the form of a credit line, without assuming the debts of the receiving Member State. ${ }^{\text {XIII }}$ Moreover, it is worth noting that the ECJ highlighted the relevance of the strict conditionality measures attached to the financial assistance in guaranteeing the consistency of commitments undertaken by the Euro-area MS with EU law. Indeed, according to the ECJ,

"the conditionality prescribed $[\ldots]$ does not constitute an instrument for the coordination of the economic policies of the Member States, but is intended to ensure that the activities of the ESM are compatible with, inter alia, Article 125 TFEU and the coordinating measures adopted by the Union". xxIv

Thus, the ECJ has interpreted these conditions as key factors for ESM compatibility with the no bail out clause and the coordinating measures adopted by the EU. Xxv 


\section{ESM and the strict conditionality rule as a vulnus to human rights protection}

I argue that it is these conditionality measures, set out in the MoUs, and interpreted by the ECJ as important for the consistency of ESM's financial assistance with the EU law, that are controversial.

Indeed, such measures usually impose cutbacks in welfare expenditures, namely pension funds, social insurance schemes, healthcare, and education. In the name of macroeconomic adjustments, the MoUs have already prescribed, for instance, a reduction in pharmaceutical spending, a decrease in the minimum wage and suspension of collective bargaining agreements (Poulou 2014: 1147-1148; Karger 2014: 33-53). Such prescriptive conditions are usually extremely detailed and peremptory; for instance, the MoU signed by the Greek Government with the EFSF imposed a progressive reduction of a specific number of personnel in public entities, an increase of the retirement age by two years starting in January 2013, the re-capitalization process for the banking sector, and a program for controlling pharmaceutical spending. ${ }^{\mathrm{XxVI}}$

As a consequence, human rights protection is therefore seriously threatened, a concern shared by some legal scholars, who have highlighted that

" $[t]$ he strict conditionality contained in the MoU may very well and very directly impinge on the social and economic rights of the EU citizens" (Schwarz 2014: 398; see also Tomkin 2013: 187, and also Salomon 2015).

The effects of economic adjustment programs on social and economic rights have also been highlighted by the UN General Assembly, in a series of Reports about the effects of foreign debt and other related financial obligations of States on the full enjoyment of all human rights, particularly economic, social and cultural rights. ${ }^{\text {xxvII }}$ Specifically, these reports have given evidence for the impact of economic management on several aspects: work, social security, health, education, adequate housing, poverty and social exclusion, and other rights such as civil and political rights. The report of the Independent Expert concerning Greece, ${ }^{\mathrm{XXVII}}$ in particular, has clarified that 
"[t]he measures implemented as part of adjustment, in particular the job cuts, and cuts to wages and pensions, have had the overall effect of compromising the living standards of the population and the enjoyment of human rights. According to the National Ombudsman, 'the drastic adjustments imposed on the Greek economy and society as a whole have had dramatic consequences on citizens, while vulnerable groups increase and multiply' [...]. In a similar vein, the National Human Rights Commission observed a 'rapid deterioration in living standards coupled with the dismantling of the welfare State and the adoption of measures incompatible with social justice, which are undermining social cohesion and democracy' [...]".xxIx

According to the report, in Greece there have been specific examples of an exponential rise in unemployment ${ }^{\mathrm{xxx}}$ and a substantial reduction in unemployment benefits, pensions and family benefits. ${ }^{\mathrm{Xxx}}$ In addition, the cuts in health care spending have led to the resurfacing of illnesses that had been eradicated in the country, such as malaria, ${ }^{\mathrm{XXII}}$ and an increase in HIV infections and mental health problems has been reported. ${ }^{\mathrm{XXXII}}$ Lastly, the cuts on social expenditures have led to the closure of schools and the reduction in numbers of teachers ${ }^{\mathrm{XXXIV}}$ as well as an increase in homelessness. ${ }^{\mathrm{XxxV}}$ The rise of poverty has also caused numerous protests in the country, which has led the national authorities to adopt several security measures; this in turn has raised concerns with regard to the freedom of assembly and association. ${ }^{\text {xxyv }}$

In this way, therefore, human rights protection is seriously threatened, in particular those human rights enshrined in the Charter of Fundamental Rights of the European Union (CFREU), in the European Convention on Human Rights (ECHR) and its Protocols and in the International Covenant on Economic, Social and Cultural Rights (ICESCR). Specifically, conditionality measures could affect social rights such as: the right to education, enshrined in Article 14 of CFREU, Article 2 of Protocol No. 1 to the ECHR, and Article 14 CESCR; the right to social security and social assistance provided for in Article 34 of CFREU; the right to social security enshrined in Article 9 of CESCR; and the right to health enumerated in Article 35 CFREU and in Article 12 CESCR. Moreover, such conditionality could affect the right to property enshrined in Article 17 of CFREU and in Article 1 of Protocol No. 1 to the ECHR, ${ }^{\text {XxvII }}$ as can happen, for instance, when 
adjustment programs impose a reduction in the value of bank deposits or cuts of salaries or pensions.

Given the potential for infringements of the human rights provisions, the issue regarding the responsibility for human rights violations then arises. Particularly, it could be questioned whether the ESM itself, the EU institutions involved in the ESM, or the Euroarea MS could bear any responsibility for the ESM's decisions affecting the human rights of citizens in assisted States. A legal scholar has already addressed similar issues on a global level regarding the IMF and the World Bank (WB) (De Sena 2010).

\section{Strict conditionality and responsibility}

4.1. The legal nature of the ESM and its (lack of) responsibility for human rights violations

In order to address the ESM's potential responsibility and the possibility of filing suits against it before an international court, it is necessary to understand the legal nature of the ESM and whether it is bound by human rights law.

The first question, namely that of the ESM's legal nature, is not clearly answered by the wording of the ESM Treaty. Indeed, while Article 1 of the Treaty defines the ESM as an "international financial institution", this is an expression notable for its ambiguities, as pointed out by Napolitano, who has highlighted that, although created by an international agreement, the ESM has a European dimension, which makes it quite close to a European agency (Napolitano 2012). According to Napolitano, this dimension is seen in several of its characteristics, such as the ESM Treaty's link to EU primary law, its peculiar membership composed only of EU MS, the role played by the EC and the ECB, and the ESM's complementarity with European monetary and economic policy. Other legal scholars, conversely, argue that the ESM in fact constitutes an international organization (Ruffert 2011: 1783 and 1790; Schwarz 2014: 400). The ESM, indeed, has been established by an international treaty and has its own governance.

With regard to the second question, namely whether the ESM is bound by human rights law, some legal scholars affirm that the ESM should respect EU principles in this area. In fact, the ESM Treaty itself requires the EC to act cohesively with EU law, and the MoUs must be 
"fully consistent with the measures of economic policy coordination provided for in the TFEU, in particular with any act of European Union law, including any opinion, warning, recommendation or decision addressed to the ESM Member concerned". xxxvIII

However, this requirement to respect EU law is confined to a narrow sector, namely EU provisions on economic policy coordination and EU acts specifically addressing the ESM.

Indeed, as von Bogdandy and Ioannidis affirmed, the ESM is an international instrument completely separate from the TEU and the TFEU systems (von Bogdandy and Ioannidis 2014: 94), which means that it is not bound by the EU fundamental rights enshrined in the CFREU. Thus, since the ESM is placed outside the EU and within its own Treaty, with no reference to the CFREU, consequently the validity of an ESM decision could not be challenged in light of that legal text.

The ECJ in the Pringle case expressly excluded the possibility of taking the CFREU into consideration within the ESM framework. Specifically, the ECJ affirmed that the Euro-area MS were not prevented from signing the ESM Treaty in the light of EU fundamental rights, in particular the general principle of effective judicial protection, the right to an effective remedy and the general principle of legal certainty, enshrined in Article 47 of the CFREU. ${ }^{\text {xxix }}$ Such concerns were raised because Article 37(2) of the ESM Treaty affirms that "the Board of Governors shall decide on any dispute arising between an ESM Member and the ESM, or between ESM Members, in connection with the interpretation and application of the ESM Treaty". XL Only if "an ESM Member contests [that] decision [...], the dispute shall be submitted to the Court of Justice". XLI

In light of these provisions, the question was raised as to whether the ESM Treaty was consistent with the CFREU. On this point, the ECJ recalled that, under Article 51(1) of the CFREU, the provisions of the CFREU apply to the MS when they are implementing Union law. The ECJ also affirmed that this situation does not occur when MS establish a stability mechanism such as the ESM, ${ }^{\mathrm{XLII}}$ which stands outside of the EU.

The inapplicability of the CFREU to the ESM Treaty therefore impedes assigning direct responsibility to the ESM for human rights violations in light of it. 
Such a responsibility cannot arise from the ECHR or the CESCR either, since the ESM is not part of those Agreements. Finding that the ESM bears responsibility based on jus cogens, then, is unrealistic, since, as De Sena already explained with regard to the IMF and the $\mathrm{WB}$, it is unlikely that the ESM itself commits strong violations of human rights (De Sena 2010).

Thus, it is difficult to identify the ESM's direct responsibility for violations of human rights caused by conditionality measures; one may wonder, however, whether it is possible that the EU institutions and the ESM's MS could be responsible for ESM actions that violate these rights.

\subsection{The ESM's measures and the potential responsibility of EU institutions}

The issue of the responsibility of EU institutions involved in the ESM for acts adopted by the latter that affect human rights arises for two reasons: first, because of the EU institutions' relevant role in granting financial assistance within the framework of the ESM, and second, because even in that framework such institutions should respect EU law in general, and human rights in particular. The Advocate General Kokott had clearly expressed this assumption with regard to the Pringle case, where she affirmed that

"[t]he Commission remains, even when it acts within the framework of the ESM, an institution of the Union and as such is bound by the full extent of European Union law, including the Charter of Fundamental Rights" xLIII

However, the potential responsibility of the EU institutions have subsequently been denied by the European General Court (GC), which is part of the ECJ, in the set of orders regarding Cyprus. ${ }^{\text {XLIV }}$ There, the applicants filed several suits against the EC's and ECB's acts, assuming, in particular, the inconsistency of some of the conditions negotiated by the former and set in the MoU.

These cases arose from the recapitalization of a number of banks established in Cyprus, which experienced financial difficulties during 2012. At that time, in order to recapitalize them, the Republic of Cyprus petitioned the President of the Eurogroup for financial assistance from the EFSF or the ESM. The Eurogroup approved the request on 27 June 2012, indicating that either the EFSF or the ESM would provide the financial assistance 
requested in the framework of a macro-economic adjustment program to be set out in the MoU. The Republic of Cyprus and the other Euro-area MS reached a political agreement on a draft MoU in March 2013.

With a view to signing the final draft, Cyprus adopted two laws providing for the recapitalization of two banks, "Trapeza Kyprou Dimosia Etaira Ltd" (BoC) and "Cyprus Popular Bank Public Co Ltd" (Laiki). This re-capitalization happened at the expense of its uninsured depositors, shareholders and bondholders (in particular, some deposits were converted into shares or other financial instruments and some deposits were transferred by Laiki to BoC). ${ }^{\mathrm{XLV}}$

This macro-economic adjustment program, which entailed a reduction of bank deposits, was approved by the Eurogroup. After this approval, not in itself required by the ESM Treaty, ${ }^{\mathrm{XLVI}}$ the ESM Board of Governors mandated that the EC sign the MoU on behalf of the ESM. The MoU, which was signed on 26 April 2013, specifically favoured the restructuring plan adopted by Cyprus, particularly taking into consideration the measures related to the aforementioned banks.

Since these measures resulted in a substantial reduction in the value of bank deposits, though, suits were filed before the GC against the EC and the ECB on the basis of the property right enshrined in Article 17 of the CFREU and in Article 1 of the ECHR Protocol No. 1.

The GC, however, pointed out that the MoU was in fact adopted by the ESM, not by the EU institutions, and the MoU merely approved the measures already adopted by the Republic of Cyprus. Therefore, the GC dismissed the actions as inadmissible in part and in part manifestly lacking any foundation in law.

The GC thus denied that there was any worth in the behavior of EU institutions involved in the MoU negotiations or in the approval of conditionality rules adopted by the Republic of Cyprus, even after the lengthy negotiations at the EU level that were guided by a process that involved EU institutions and the Eurogroup. Moreover, the GC affirmed the non-applicability of the CFREU because the ESM is set outside the EU. However, pursuant to Article 13 TEU, the EU institutions "shall aim to promote [the EU's] values, advance [the EU's] objectives, serve [the EU's] interests, those of [the EU] citizens and those of the Member States"; it is worth noting that this Article does not confine the EU institutions' aims strictly within the EU framework. Thus, as the Advocate General Kokott 
affirmed, the EU institutions should be considered bound by the full extent of EU law, including the Charter of Fundamental Rights, when acting within the ESM's framework.

\subsection{The ESM's measures and the potential responsibility of Member States}

In addition to EU institutions, the question arises as to whether the ESM's shareholders - namely the Euro-area MS - could be responsible for acts that the ESM adopted.

In this perspective, the responsibility of Euro-area MS could be derived from the ICESCR (to which all the ESM's MS are parties).

Specifically, this possibility could be derived following, mutatis mutandi, the reasoning of De Sena regarding the responsibility of State members of the WB and the IMF for acts adopted by these financial institutions (De Sena 2010).

Indeed, according to Article 2(1) of the ICESCR,

"[e]ach State Party to the [...] Covenant undertakes to take steps, individually and through international assistance and co-operation, especially economic and technical, to the maximum of its available resources, with a view to achieving progressively the full realization of the rights recognized in the present Covenant by all appropriate means, including particularly the adoption of legislative measures".

According to De Sena, such a "progressive obligation" requires MS to use due diligence to ensure that financial institutions contribute to human rights in their financial assistance activities (De Sena 2010: 257). Within the WB and the IMF, this contribution could be made during the decision-making process, since the IMF Executive Board and WB Board of the Executive Directors, two bodies composed of representatives from MS, adopt their decisions according to an absolute majority rule. Therefore,

"member States do not lack the possibility of acting to ensure that the conditionality clauses comply with the needs stemming from the ICESCR" (De Sena 2010: 259). And "it is precisely in the absence of any effort in this regard that they commit a violation of the general obligation envisaged by Article 2 of the Covenant" (De Sena 2010: 259). 
The same reasoning could be applied within the ESM's framework, for in this case also it is the members who represent States that then adopt its decisions. Specifically, these decisions are adopted by two bodies - the Board of Governors and the Board of Directors - composed of persons appointed by governments, who are revocable at any time. ${ }^{\mathrm{XLVII}}$ The Euro-area MS can, thus, steer ESM decisions on financial assistance and conditionality measures.

However, although State responsibility could stem from the ICESCR, the guarantees enshrined therein are difficult to implement for two reasons. Firstly, to date many ESM States are not parties to the Optional Protocol to the ICESCR, ${ }^{\text {XLVIII }}$ which would allow individuals or other Members to submit a communication to the UN Committee for Human Rights. Secondly, there are challenges in demonstrating the causal link between the claimed violation and the State's behavior within these financial institutions. ${ }^{\text {XIIX }}$

Because of the link between the ESM's decisions and the Euro-area MS, the latter's responsibility could also be derived from the ECHR, and Protocol No. 1 of the ECHR, which all the ESM MS have ratified, and on the basis of which an action could be brought by individuals before the European Court of Human Rights (ECtHR).

In light of this Protocol, conditionality measures could infringe the right to property enshrined in Article 1, as a consequence of cuts to public expenditures or where conditionality affects banks' depositors, shareholders and bondholders. Moreover, a violation of Article 2 ECHR (namely a violation of the right to education), could arise as a consequence of cuts to public expenditures specifically where social expenditures in educational systems are concerned.

However, within the ECHR framework, the guarantees enshrined in the ECHR and in the ECHR Protocol No. 1 seem difficult to implement because of the challenges in demonstrating the causal link between the claimed violation and the State's behavior within these financial institutions. Thus, de facto, identifying the responsibility of ESM MS for financial measures that infringe their own human rights provisions is unrealistic.

A finding of a possible violation of the ECHR by the State that adopts the economic adjustment measures in order to receive financial aid is also unrealistic, due to the wide margin of discretion that States enjoy in social and economic matters. The question regarding the compatibility of such national measures arose in Koufaki and Adedy v. Greece, where the applicants claimed that cuts in public servants' wages and pensions were 


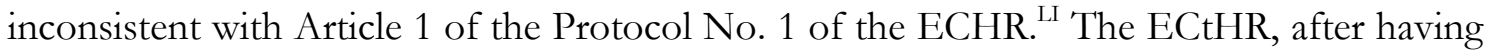
evaluated the Greek law that provided the basis for the reductions in question, affirmed that

"[...] the notion of "public interest" is necessarily extensive. As it has already noted, the decision to enact laws to balance State expenditure and revenue will commonly involve consideration of political, economic and social issues, and the margin of appreciation available to the legislature in implementing social and economic policies is a wide one". ${ }^{\text {II }}$

According to the ECtHR, then, a fair balance was struck between the general interests of the [Greek] community and the requirement to protect the fundamental rights of the applicants. $^{\text {LIII }}$

One last consideration is whether there is some potential legal basis to invoke the responsibility of the ESM MS for the circumvention of obligations as State members of an international organization. Such a suggestion, as De Sena has already pointed out with regard to the IMF and the WB (De Sena 2010), finds some confirmation following Article 61 of the 2011 Draft of Article on the Responsibility of International Organizations (DARIO), according to which

"[a] State member of an international organization incurs international responsibility if, by taking advantage of the fact that the organization has competence in relation to the subject-matter of one of the State's international obligations, it circumvents that obligation by causing the organization to commit an act that, if committed by the State, would have constituted a breach of the obligation". LIV

However, as legal scholars have pointed out, in the 2011 version of DARIO Article 61, the International Law Commission "decided in favor of a subjective concept - other than in the preliminary version of DARIO Article 61 where an objective approach had been pursued” (Möldner 2011: 321, fn 153). Specifically, the Commentary regarding Article 61 affirms that the term "circumvention" implies "the existence of an intention to avoid compliance" (Möldner 2011: 321), thus requiring a difficult burden of proof. ${ }^{\mathrm{LV}}$ 


\section{Final remarks}

This analysis has shown that the tools established to tackle Euro-area MS' difficulties in fact give rise to human rights concerns because of the conditionality measures attached to economic adjustment programs.

Furthermore, this analysis has illustrated the difficulty in invoking any responsibility for possible infringements of human rights provisions.

Primarily, the ESM itself is not bound by human rights treaties, and the possibility to recall jus cogens seems not to be a viable option.

Secondly, the ECJ has also denied any possible responsibility of EU institutions involved in such a financial mechanism because the ESM is set outside EU law. This is true of course. But, while EU institutions might be acting within the confines of the ESM, they should respect EU law, including the CFREU. Such a circumstance could be inferred by Article 13 TEU, and moreover has been highlighted by the Advocate General Kokott in her opinion regarding the Pringle case. The latter's suggestion, expressed with regard to the Pringle case was, however, not even considered by the ECJ in the set of rulings regarding Cyprus, where the Court was expressly required to consider the possible responsibility of the $\mathrm{ECB}$ and the EC in light of potential fundamental rights breaches.

Lastly, the responsibility of Eurozone Member States, which are parties to the ESM, although theoretically possible, is de facto unrealistic.

Thus, in this realm, possible violations of human rights depending on conditionality measures are not likely to be remedied through the traditional legal channels.

This scenario would probably change if the ESM was to be set within the EU legal system. Indeed, as it would then be a body of the EU, it would certainly have to act in cohesion with the full extent of EU Law, and thus with the CFREU.

The possibility of linking the mechanisms to manage crisis situations (such as the ESM) to the EU system has been already considered by legal scholars (Schwarz 2014; see also Gallo 2015: 31); such a possibility, however, inevitably implies a new political will to reform the current legal framework governing financial aid within the Eurozone.

\footnotetext{
* PhD in International Law at the University of Padua; fellow in EU law and Private International Law at the University of Padua (arianna.vettorel@,unipd.it).
} 


\begin{abstract}
I Art. 125 TFEU (ex 103 EC).
II Art. 123 TFEU (ex 101 EC): 'Overdraft facilities or any other type of credit facility with the European Central Bank or with the central banks of the Member States (hereinafter referred to as 'national central banks') in favour of Union institutions, bodies, offices or agencies, central governments, regional, local or other public authorities, other bodies governed by public law, or public undertakings of Member States shall be prohibited, as shall the purchase directly from them by the European Central Bank or national central banks of debt instruments'. The clause is aimed at avoiding the risk of moral hazard.
\end{abstract}

III O.J. 2010, L 118/1, “Council Regulation (EU) No 407/2010 of 11 May 2010 establishing a European financial stabilisation mechanism".

IV See $\operatorname{COM}(2010) 713$, "Communication from the Commission to the Council and the Economic and Financial Committee on the European Financial Stabilization Mechanism”, Brussels, 30.11.2010.

$\mathrm{V}$ The text of the EFSF statute and the other legal documents are available at http://www.efsf.europa.eu/about/legal-documents/index.htm (last visited 15 Dec. 2015).

VI According to Art. 4 of the EFSF Consolidated Articles of Association ,(available at http://www.efsf.europa.eu/about/legal-documents/index.htm, last visited 15 Dec. 2015) "[n]o new financing program and no new loan facility agreements will be established or entered after 30 June 2013", even if the general meeting of shareholders could unanimously extend this date. The Irish financial assistance program concluded on 8 December 2013; the Portuguese one ended on 18 May 2014. The Greek program, instead, has been extended until 28 February 2015. Data available at http://www.efsf.europa.eu/about/operations/index.htm (last visited 15 Dec. 2015).

VII See the Preamble, point 2, of the EFSF Framework Agreement, available at http://www.efsf.europa.eu/attachments/20111019 efsf framework agreement en.pdf (last visited 15 Dec. 2015).

VIII See, in particular, Art. 40 ("Transfer of EFSF supports") of the ESM Treaty (T/ESM 2012-LT). The text of the Treaty is available at http://www.esm.europa.eu/about/legal-documents/index.htm (last visited 15 Dec. 2015).

IX See the Preamble, point 6, of the ESM Treaty. During a transitional period, ended in June 2013, the EFSF and the ESM granted financial assistance in parallel, with a total lending capacity of 700 billion Euro.

x O.J. 2011, L 91/1, "European Council Decision of 25 March 2011 amending Article 136 of the Treaty on the Functioning of the European Union with regard to a stability mechanism for Member States whose currency is euro", 2011/199/EU.

XI According to the procedure established by Art. 48 TFEU, the Decision 2011/199 added a third paragraph to Art. 136 TFEU: "The Member States whose currency is the euro may establish a stability mechanism to be activated if indispensable to safeguard the stability of the euro area as a whole. The granting of any required financial assistance under the mechanism will be made subject to strict conditionality".

XII TSCG, available at http://www.consilium.europa.eu/en/workarea/downloadAsset.aspx?id=27066 (last visited 15 Dec. 2015).

XIII See http://www.esm.europa.eu/assistance/index.htm (last visited 15 Dec. 2015).

XIV In particular, the Governor shall be an individual from an ESM Member's Government who has responsibility for financial decisions within his or her Member State. Every ESM Member shall appoint an alternate Governor. See Art. 5 of the ESM Treaty.

$\mathrm{xV}$ The membership of the Board of Directors is explained by Art. 6 ESM Treaty, which, after providing that "[e]ach Governor shall appoint one Director and one alternate Director from among people of high competence in economic and financial matters", affirms that "[s] uch appointments shall be revocable at any time".

XVI Art. 13(1) ESM Treaty.

XVII Art. 13(3), ESM Treaty.

XVIII Art. 13(4), ESM Treaty.

xIx Art. 13(5), ESM Treaty.

xx ECJ, Case C-370/12, Thomas Pringle v Governement of Ireland, Ireland and The Attorney General, nyr in ECR.

xxI The Decision No. 2011/199 was adopted on the basis of Art. 48 TFEU, which concerns the simplified revision process. However, since this process can be used only with regard to Part Three of the TFEU and cannot increase the competences of the EU, the referring court asked whether such conditions were met by this Decision. Specifically, with regard to the first condition, namely whether the Decision dealt with only Part Three of the TFEU, the referring court highlighted the potential impact of the establishment of a permanent stability mechanism on the common monetary policy, enshrined in the Part One of the TFEU 
and on which the EU has an exclusive competence. Since the TFEU does not provide any specific definition of monetary policy, the ECJ gave its interpretation in light of the different objectives pursued by the common monetary policy and the ESM. While the former is aimed at maintaining price stability, the latter is aimed at safeguarding the stability of the Euro area as a whole. Thus, according to the ECJ, "[e]ven though the stability of the euro area may have repercussions on the stability of the currency used within that area, an economic policy measure cannot be treated as equivalent to a monetary policy measure for the sole reason that it may have indirect effects on the stability of the euro" (Case C-370/12, Pringle, para 56). For this reason, according to the ECJ, the ESM does not concern Part One of the Treaty. With regard to the second condition, namely whether this Decision would have increased the competences of the EU, the ECJ affirmed that the amendment of Art. 136 TFEU did not create any legal basis for the EU to be able to take any action that was not also possible prior to the amendment. Specifically, according to the ECJ, "[e]ven though the ESM Treaty makes use of the Union's institutions, in particular the Commission and the ECB, that fact is not, in any event, capable of affecting the validity of Decision 2011/199, which in itself provides only for the establishment of a stability mechanism by the Member States and is silent on any possible role for the Union's institutions in that connection" (Case C-370/12, Pringle, cit., para 74). Thus, Decision 2011/199 did not increase the competences conferred on the EU in the Treaties.

XXII The Court also stated that Member States are allowed to enter into an international agreement between themselves, provided that the commitments undertaken by the Member States who are party to such an agreement are consistent with EU law. Specifically, the ECJ affirmed that the ESM does not prevent the Council of the European Union to decide, in a spirit of solidarity between Member States, upon measures appropriate to the economic situation, according to Article 122 TFEU. See Case C-370/12, Pringle, para 109. xxIII Case C-370/12, Pringle, para 139.

XXIV Ivi, para 111.

xxv Ibidem.

xxvi See European Commission, "The Second Economic Adjustment Programme for Greece. First Review December 2012”, Occasional Papers 123/December 2012, available at http://ec.europa.eu/economy finance/publications/occasional paper/2012/pdf/ocp123 en.pdf (last visited 15 Dec. 2015) at 205, 209, 210-211.

XXVII Report of the independent expert on the effects of the foreign debt and other related international financial obligations of States on the full enjoyment of all human rights, particularly economic, social and cultural rights, at http://www.ohchr.org (last visited 15 Dec. 2015).

XXVIII UN General Assembly, Report of the Independent Expert on the effects of foreign debt and other related international financial obligations of States on the full enjoyment of all human rights, particularly economic, social and cultural rights, Cephas Lumina, Mission to Greece (22 - 27 April 2013), 27 March 2014, available at http://www.ohchr.org (last visited 15 Dec. 2015).

XXIX $I v i$, at 12 .

xxx According to the report, "unemployment grew from 7.3 per cent in June 2008 to 27.9 per cent in June 2013, the highest in the European Union". Moreover, "[y]outh unemployment reached an unprecedented rate of 64.9 per cent in May 2013 (compared with an average of 24.4 in the euro zone)", ivi at 13.

Xxxi The report also registered that "[o]wing to the rise in long-term unemployment, only a fraction of all registered unemployed persons receive benefits (27 per cent as at February 2013). Moreover, unemployment benefits expire after 12 months, resulting in the loss of public health insurance cover. Many young people are not eligible for support because they have never had a job and have not paid the required national insurance contributions. [...] These wholesale pension cuts have pushed a large proportion of the population into poverty. [...] The Independent Expert shares the view of the European Committee of Social Rights that the 'cumulative effect' of the various laws introduced as 'austerity measures' in Greece since May 2010, restricting and reducing both public and private pension benefits, constituted a violation of the right to social security enshrined in article 12(3) of the European Social Charter". Ivi, at 15-16.

xxxII According to the report, such illness has resurfaced owing to the discontinuation of anti-mosquito spraying programmes. Ivi, at 17.

xxxiII Ibidem.

xxxiv Ivi, at 19 .

xxxv $I v i$, at 20.

xxxvi The International Expert reported that "[i]n May 2013, the Government invoked national emergency legislation allowing it to compel public sector employees to work to ban a planned strike by the National Union for High School Teachers against austerity measures during university entrance examinations. [...] 


\begin{abstract}
There has also been a rise in hate crimes and xenophobia against the country's immigrant community, largely targeted in an attempt to find a scapegoat for the crisis. [...] In April 2013, the National Commission for Human Rights (UNHCR) and a coalition of 30 non-governmental organizations documented 154 incidents of racist violence in 2012 alone, of which 151 committed against refugees and migrants and three against European citizens. It is believed that most attacks were committed by members of extremist groups, and that only a fraction of all cases are actually documented. [...] Lastly, the enjoyment of human rights has been further undermined by the limited ability of public accountability bodies, such as the Greek Ombudsman and the National Commission for Human Rights, to respond adequately to human rights issues in the context of the economic crisis owing to insufficient funding for operations. Other barriers to access to justice include lengthy proceedings before civil and administrative courts, higher fees for initiating legal proceedings and inadequate funding for legal aid". Ivi, at 21-22.
\end{abstract}

xxxvII On this topic, see infra paras 4.2. and 4.3.

xxxvIII Art. 13(3) ESM Treaty.

xxxix Case C-370/12, Pringle, para 178-180.

xL Art. 37(2) ESM Treaty.

XLI Art. 37(3) ESM Treaty.

XLII Case C-370/12, Pringle, para 180.

XLIII View of Advocate General Kokott, Case C-370/12, Pringle, nyr in ECR, para 176.

XLIV GC, Case T-289/13, Lerda Advertising v. Commission and ECB, nyr in ECR; GC, Case T-290/13, CMBG v. Commission and ECB, nyr in ECR; Case T-291/13, Eleftheriou and Papachristofi v. Commission and ECB, nyr in ECR; Case T-292/13, Evangelou v. Commission and ECB, nyr in ECR; Case T-293/13, Theophilou v. Commission and ECB, nyr in ECR; Case T-294/13, Fialtor v. Commission and ECB, nyr in ECR. All orders were issued on 10 November 2014.

XLV Specifically, uninsured deposits were converted into BoC shares (37.5\% of each uninsured deposit), into instruments that were convertible by $\mathrm{BoC}$ either into shares or into deposits $(22.5 \%$ of each uninsured deposit), and into instruments which were convertible into deposits by Central Bank of Cyprus (40\% of each uninsured deposit). Additionally, certain assets and liabilities were transferred from Laiki to BoC, including deposits of up to Euro 100,000. Deposits over Euro 100,000 remained with Laiki, pending its liquidation. See GC, Case T-289/13, Lerda Advetising, para 17-18; Case T-290/13, CMBG, para 17-18; Case T-291/13, Eleftheriou, para 17-18; Case T-292/13, Evangelou, para 17-18; Case T-293/13, Theophilou, para 17-18; Case T294/13, Fialtor, para 17-18.

XLVI Only within the EFSF did the Eurogroup Working Group play a role in granting financial assistance. See Art. 2, EFSF Framework Agreement.

XLVIIArt. 5(1) and Art. 6(1) ESM Treaty.

XLVIII Data available at http://indicators.ohchr.org/ (last visited 15 Dec. 2015).

XLIX It is precisely for that reason that De Sena highlighted the role played by inter-State communications "to bring to the fore violations raising issue of 'general importance', since such communications are not required to show - in order to be received by the Committee - that a 'clear disadvantage' has been suffered as a consequence of the alleged violation" (De Sena 2010: 261).

L ECtHR, Koufaki and Adedy, 7 May 2013, App. No 57665/12 and 57657/12, available at http://www.echr.coe.int/ (last visited 15 Dec. 2015).

LI The first applicant was a member of the Athens Bar, who worked as a member of the scientific staff of the Greek Ombudsman's Office and was later seconded to the central department of the Technical Chamber of Greece, a corporate body governed by public law. Thus, her pay was governed by laws on the salary rules applicable to public servants and public-sector employees. The second applicant was a trade union organisation representing several unions of public-sector workers employed on a permanent basis or under private law by the State, corporations governed by public law and the local and regional authorities. During 2010, the Greece Government adopted a law that reduced the pay of persons working in the public sector irrespective of their employment status - by a percentage ranging from $12 \%$ to $30 \%$, notwithstanding any other specific or general legislation, collective agreement, arbitration ruling or individual agreement or contract. Ivi, paras 3 and 4.

LII Ivi, para 39.

LIII The Court considers that "the extent of the reduction in the first applicant's salary was not such as to place her at risk of having insufficient means to live on and thus to constitute a breach of Article 1 of Protocol No. 1. In view of the foregoing and of the particular context of crisis in which the interference in question occurred, the latter could not be said to have imposed an excessive burden on the applicant". Ivi, 
para 46. Moreover, as to the proportionality of the impugned measures with regard to the wages and pensions of the public servants affiliated to the second applicant, the Court referred to the text of the memorandum of understanding itself and affirmed that "[a]ccording to the memorandum, the abolition of the thirteenth and fourteenth pension payments was compensated for, in the case of persons receiving less than EUR 2,500 per month, by the introduction of a flat-rate bonus of EUR 800 per year. Furthermore, while the thirteenth and fourteenth salary payments were abolished across the board, an annual bonus of EUR 1,000 was introduced, funded by the reduction in the allowances previously payable to higher earners. This bonus was introduced with the aim of protecting those in the lowest income segments (persons receiving less than EUR 3,000 per month)". Ivi, para 47.

LIV Art. 61 of DARIO.

LV On the conditions for international responsibility to arise, see the Commentary to Art. 61 DARIO.

\section{References}

- Dawson Mark and de Witte Floris, 2013, 'Constitutional Balance in the EU after the Euro-Crisis', The Modern Law Review, LXXV(5): 817-844.

- de Lhoneux Etienne and Vassilopoulos Christos A., 2014, The European Stability Mechanism Before the Court of Justice of the European Union. Comments on the Pringle Case, Springer.

- De Sena Pasquale, 2010, 'International Monetary Fund, World Bank and Respect for Human Rights: A Critical Point of View', The Italian Yearbook of International Law, XX: 247-274.

- de Witte Bruno, 2000, 'Old-fashioned Flexibility: International Agreements between Member States of the European Union', in De Búrca Grainne - Scott Joanne (eds), Constitutional Change in the EU: From Uniformity to Flexibility?, Hart Publishing, Oxford, 31-58.

- de Witte Bruno, Beukers Thomas, 2013, 'The Court of Justice approves the creation of the European Stability Mechanism outside the EU legal order: Pringle', Common Market Law Review, L(3): 805-848.

- Gallo Franco, 2015, Giustizia sociale e giustizia fiscale nell'Unione europea. Fra integrazione e unificazione, Editoriale Scientifica, Napoli.

- Joerges Christian, 2014, 'Europe's Economic Constitution in Crisis and the Emergence of a New Constitutional Constellation', German Law Journal, XV(V): 985-1027.

- Karger Howard, 2014, 'The Better Pill: Austerity, Debt, and the Attack on Europe's Welfare States', Journal of Sociology \& Social welfare XLI(2): 33-53.

- Klabbers Jan, 2008, Treaty Conflict and the European Union, Cambridge University Press, Cambridge.

- Louis Jean-Victor, 2010, 'Guest Editorial: the No-bailout Clause and Rescue Packages', Common Market Law Review, XLVII(4): 971-986.

- Möldner Mirka, 2012, 'Responsibility of International Organizations - Introducing the ILC's DARIO', in von Bogdandy Armin - Wolfrum Rüdiger (eds), Max Planck Yearbook of United Nations Law, Brill, vol. 16, 281-328.

- Napolitano Giulio, 2012, 'Il Meccanismo europeo di stabilità e la nuova frontiera costituzionale dell'Unione', Giornale di diritto amministrativo, XIV(5): 461-469.

- Poulou Anastasia, 2014, 'Austerity and European Social Rights: How Can Courts Protect Europe's Lost Generation', German Law Journal, XV(6): 1145-1176.

- $\quad$ Ruffert Matthias, 2011, 'The European debt crisis and European Union Law', Common Market Law Review, XLVIII(6): 1777-1805.

- Salomon Margot E., 2015, 'Of Austerity, Human Rights and International Institutions', LSE Law, Society and Economy Working Papers 2/2015 London School of Economics and Political Science Law Department, available at www.lse.ac.uk/collections/law/wps/wps.htm (last visited 15 Dec. 2015) and at http://ssrn.com/abstract $=2551428$ (last visited 15 Dec. 2015).

- Schwarz Michael, 2014, 'A Memorandum of Misunderstanding - the Doomed Road of the European Stability Mechanism and a Possible Way Out: Enhanced Cooperation', in Common Market Law Review, LI(2): 389-423.

- Tomkin Jonathan, 2013, 'Contradiction, circumvention and conceptual gymnastics: the impact of the adoption of the ESM Treaty on the state of European democracy’, German Law Journal, XIV(1): 169-190. 
- Van Malleghem Pieter Augustijn, 2013, 'Pringle: A Paradigm Shift in the European Union's Monetary Constitution', German Law Journal, XIV(1): 141-168.

- von Bogdandy Armin and Ioannidis Michael, 2014, 'Systemic deficiency in the rule of law: what it is, what has been done, what can be done', Common Market Law Review, LI(1): 59-96. 